\title{
Effects of two different diets on carcass and meat quality traits of Chato Murciano pigs
}

\author{
BEGOÑA PEINADO, LAURA ALMELA, NELSON DUCHI and ANGEL POTO
}

Murcian Institute of Agricultural and Alimentary Research and Development, Murcia, Spain

\begin{abstract}
A total of 40 castrated male pigs of the Spanish autochthonous Chato Murciano breed were used for this study to evaluate the influence of two diets. One group of 20 pigs was fed with a high protein/low fat (HP/LF) diet and slaughtered with life weight (LW) of $125.03 \mathrm{~kg}$. The other group of 20 pigs was fed with a low protein/high fat (LP/HF) diet and slaughtered with $121.91 \mathrm{~kg} \mathrm{LW}$. The effects of diet on carcass and meat quality traits were studied. Meat samples were taken from the longissimus lumbar (LL) muscle. The HP/LF diet produced a faster growing rate and higher daily weight gain, and measurements in the LL muscle showed higher values of ultimate $\mathrm{pH}(\mathrm{pHu})$, colour parameters, and higher content in $\mathrm{Ca}, \mathrm{Mg}, \mathrm{Zn}, \mathrm{K}$ and $\mathrm{Na}$. The LP/HF diet led to higher values of Fe and $\mathrm{Cu}$. The difference in the LL muscle intramuscular fat (IMF) levels was noteworthy, with values of $3.21 \%$ in the HP/LF group and $11.00 \%$ in the LP/HF group; however, the dorsal fat thickness measurements showed no differences. The fatty acid composition of the IMF was 42.43 and $42.29 \%$ of saturated fatty acids (SFA), 50.34 and $51.35 \%$ of monounsaturated fatty acids (MUFA) and 7.20 and $6.24 \%$ of polyunsaturated fatty acids (PUFA) for the HP/LF group and LP/HF group respectively, with only statistically significant differences in the MUFA levels $(P \leq 0.05)$.
\end{abstract}

Keywords: pigs, Chato Murciano, diet, carcass, meat quality

\section{Zusammenfassung}

\section{Einfluss zweier verschiedener Diäten auf die Schlachtkörper- und Fleischqualität von Chato Murciano Schweinen}

Für die Untersuchung des Einflusses zweier verschiedener Diäten auf die Schlachtkörperund Fleischqualität sind vierzig kastrierte männliche Schweine der spanischen lokalen Rasse Chato Murciano verwendet worden. Eine Gruppe mit 20 Schweinen ist mit einer proteinreichen bzw. fettarmen Diät (HP/LF) gefüttert worden. Die Tiere wurden mit einem durchschnittlichen Lebendgewicht (LW) von 125,03 kg geschlachtet worden. Die andere Gruppe, die ebenfalls 20 Schweine umfasste, ist mit einer proteinarmen bzw. fettreichen Diät (LP/HF) gefüttert worden. Die Tiere dieser Gruppe sind mit einem durchschnittlichen Lebendgewicht von 121,91 kg geschlachtet worden. Die untersuchten Fleischproben wurden vom Muskel Longissimus lumbar (LL) entnommen.

Als Ergebnis dieser Untersuchung zeigte sich, dass die HP/LF Diät ein schnelles Wachstum und eine hohe tägliche Gewichtszunahme verursachte. Außerdem wurden in 
dem LL-Muskel dieser Gruppe verglichen mit den Ergebnissen der LP/HF-Gruppe höhere pH-Werte (pHu), höhere Farbparametern $\left(\mathrm{L}^{*}, \mathrm{a}^{*}, \mathrm{~b}^{*}\right)$ und höhere $\mathrm{Ca}-, \mathrm{Mg}-, \mathrm{Zn}-, \mathrm{K}-$ und NaGehalte ermittelt. Die LP/HF-Diät verursachte höhere Fe- und Cu-Werte. Die Unterschiede bei den intramuskulären Fettgehalten (IMF) waren signifikant mit Werten von 3,21\% in der HP/LF-Gruppe und $11,00 \%$ in der LP/HF-Gruppe. Die Rückenspeckdicken waren jedoch ähnlich. Die Fettsäurezusammensetzung des IMF betrug 42,43 bzw. 42,29\% gesättigte Fettsäuren (SFA), 50,34 bzw. 51,35\% einfach ungesättigte Fettsäuren (MUFA) und 7,20 bzw. 6,24\% mehrfach ungesättigte Fettsäuren (PUFA) für die HP/LF- bzw. die LP/HFGruppe. Lediglich die MUFA-Werte lagen bei der LP/HF-Gruppe signifikant höher $(P \leq 0,05)$.

Schlüsselwörter: Schwein, Chato Murciano, Diät, Schlachtkörper, Fleischqualität

\section{Introduction}

In the last years, in Europe, autochthonous breeds and animal welfare has received growing attention. Many »old « regional breeds, like the Chato Murciano pig in the Region of Murcia (south-east Spain), had traditionally supplied a high sensory and nutritional meat with an important socio-economic influence, and were traditionally reared in an extensive or semi-free system. With the arrival of the commercial cross-breeds, many of these "old" breeds were substituted, because of their productive capacity and the changes in consumer habits, as they looked for a leaner meat.

It would be advisable to conscientiously evaluate the role and values of the traditional farming systems in the development of local breeds and their typical products. The Chato Murciano pig is a magnificent transformer of a great variety of food, such as farming subproducts and the residues produced in normal crop rotation, as well as domestic leftovers from family farms in the huerta (market garden) and irrigated areas (PEINADO et al. 2001). This breed stands out because of its rusticity; it is genetically adapted to the local conditions and extensive production systems, and undergoes few welfare problems. Nowadays, the Chato Murciano pig is commonly reared indoors (conventional intensive system), but also in outdoor systems, and in all cases, they receive commercial fodder.

For many years there has been a strong interest in modifying animal fat composition through feeding to meet the dietary recommendations for humans (PFEUFFER 2001, VACLAVKOVÁ and BÉCKOVÁ 2007). However, meat with a high content of PUFA may lead to meat and meat products which can be characterised as "soft", and therefore of inferior quality, and with the added problem of higher susceptibility to oxidation, that reduces the self life of the product.

The nutritional status of an animal can greatly influence skeletal muscle growth (RUUSUNEN et al. 2006). Many studies have shown that a high-protein diet results in higher weight gain, higher carcass lean meat content and lower fat content than do lowprotein diets (CHIBA et al. 2002, WOOD et al. 2003, TEYE et al. 2006).

The aim of this work was to investigate the effect of two different diets (HP/LF vs. LP/HF) on carcass and morphometric parameters, meat quality and mineral and fatty acid composition in pigs of the breed Chato Murciano pure. 


\section{Material and methods}

The animals used in this study were 40 Chato Murciano pigs, all castrated males, divided into two groups both fed ad libitum, but with two different diets. One group, of 20 pigs, was fed with a high protein/low fat diet (HP/LF group), and the other group of 20 pigs was fed with a low protein/high fat diet (LP/HF group). The animals began to receive the diets at the age of 100 days until departure to slaughterhouse. Ingredients and chemical composition, and nutritional analysis of the diets are shown in Table 1.

Table 1

Ingredients and chemical composition (\%) and nutritional analysis of the basal concentrate diet Zutaten und chemische Zusammensetzung (\%) sowie Nährwertanalyse der Diäten

\begin{tabular}{|c|c|c|}
\hline & HP/LF diet & LP/HF diet \\
\hline \multicolumn{3}{|c|}{ Ingredients and chemical composition (\%) } \\
\hline Corn & 40 & 15 \\
\hline Barley two rows & 34.8 & 34.9 \\
\hline Soybean meal $44 \%$ & 22 & 11 \\
\hline Peas springs & - & 12 \\
\hline Wheat shorts & - & 10 \\
\hline Wheat & - & 7.3 \\
\hline Alfalfa dehydrated & - & 3 \\
\hline Lard & - & 2.5 \\
\hline Calcium carbonate & 0.7 & 1.63 \\
\hline Sugarcane molasses & - & 1 \\
\hline Mono-dicalcium phosphate & 1.9 & 0.52 \\
\hline Sodium chloride & 0.3 & 0.35 \\
\hline Vitamins and minerals & 0.3 & 0.3 \\
\hline Soya oil & - & 0.25 \\
\hline Setnazyme phitase & - & 0.1 \\
\hline \multicolumn{3}{|l|}{ Nutritional analysis (\%) } \\
\hline Dry matter & 88.93 & 89.06 \\
\hline Crude protein & 17.01 & 15.00 \\
\hline Ether extract & 2.36 & 4.94 \\
\hline Crude fibre & 4.03 & 5.09 \\
\hline Ash & 5.60 & 4.89 \\
\hline $\mathrm{Ca}$ & 0.94 & 1.00 \\
\hline $\mathrm{Na}$ & 0.13 & 0.15 \\
\hline $\mathrm{P}$ (total) & 0.70 & 0.63 \\
\hline $\mathrm{Cu}$ & $28^{*}$ & $8^{*}$ \\
\hline C18:2 & 1.27 & 1.30 \\
\hline Lysine & 0.86 & 0.74 \\
\hline Methionine & 0.26 & 0.23 \\
\hline $\mathrm{DE}(\mathrm{Kcal} / \mathrm{Kg})$ & 3247 & 3218 \\
\hline ME (Kcal/Kg) & 3100 & 3077 \\
\hline
\end{tabular}

*in $\mathrm{mg} / \mathrm{kg}$, DE digestible energy, ME metabolizable energy

The animals were bred in an outdoor system, at the Experimental Station of the Murcian Institute of Agricultural and Alimentary Research and Development (IMIDA) in the Levante region of Spain. All pigs were weighed periodically, from the age of 100 days until the day of departure to slaughter. The animals were slaughtered at different ages, considering proximity to $120 \mathrm{~kg}$ of live weight as the criterion to slaughter them, because this is the 
slaughter weight traditionally used. The experimental animals were kept, maintained and treated in adherence to accepted standards for the humane treatment of animals.

The pigs were sent to a commercial slaughterhouse the day before slaughtering, without mixing animals from the two groups at any moment, and trying to minimize stress. The slaughter was realised following the Spanish Regulations (B.O.E. 12/03/1993). Carbon dioxide for stunning of animals was used just before bleeding. The variables which are used to evaluate carcass and meat quality were measured 45 min post mortem and after $24 \mathrm{~h}$ at $4^{\circ} \mathrm{C}$ : hot and cold (after $24 \mathrm{~h}$ ) weights of the carcass and the colour coordinates $L^{*}$ (luminosity index), $a^{*}$ (red index) and $b^{*}$ (yellow index) of the CIELab system were measured on LL muscle. Several morphometric parameters like carcass length $(\mathrm{CL})$, hand length $(\mathrm{HL})$, leg length $(\mathrm{LgL})$, ham length $(\mathrm{HmL})$, maximum perimeter of the ham (HmP) and wrist perimeter (WP) were measured on the hanging right half of the carcass at 45 min post mortem following the method described by PEINADO et al. (2004). The dorsal fat thickness (DFT) was measured with a gauge (Mod CD-15DC, Mituloyo Ltd., England) at the level of the first rib (DFT1), the last rib (DFT2), the craneal extreme of the gluteus medius in the area of the thickest dorsal fat (DFT3), and in the area of the least dorsal fat thickness (DFT4) of the gluteus medius ( PEINADO et al. 2004).

The carcass was quartered using traditional Murcian methods, in the plant of a collaborating meat industry firm. The cuts of meat studied (tenderloin, loin head, loin, shoulder blade and ham with bone) were weighed using calibrated scales sensitive to $100 \mathrm{~g}$ (POTO 2003).

The study of the intramuscular fat content of the LL muscle was performed using the method described in the ISO 1443 (1979) norm, with the Soxhlet extractor. The samples were taken at 45 min post mortem, and the values obtained expressed as a percentage of the weight in $\mathrm{g}$ (РОTO, 2003). The fatty acids composition of the intramuscular fat of the LL muscle was determined following the protocol from SCHULTE and WEBER (1989).

For the determination of the mineral composition ( $\mathrm{Ca}, \mathrm{Mg}, \mathrm{Fe}, \mathrm{Cu}, \mathrm{Zn}, \mathrm{P}, \mathrm{Mn}, \mathrm{K}, \mathrm{Na}$ ) approximately $1 \mathrm{~g}$ of meat was dry ashed in a Furnace oven (Nabetherm, model L9/12/S27, Germany). The results obtained for each mineral were expressed in $\mathrm{mg} / 100 \mathrm{~g}$ of raw meat. Each sample was analysed in duplicate. The analysis of the certified reference material BCR 184 (bovine muscle) was used to assure the accuracy of our procedure.

For the statistical analysis of the data obtained the program Stat graphics Plus for Windows Version 2.1 was used. Data were expressed as mean \pm standard deviation. A Scheffe Test was carried out to ascertain significant differences $(P \leq 0.05)$ between samples. Pearson correlation coefficients were evaluated to describe the relationship between the different parameters studied.

\section{Results and discussion}

The pigs were slaughtered with similar live weights and ages (Figure 1). The HP/LF group was slaughtered with an average LW of $125.03 \mathrm{~kg}$ and an average age of 225 days, and the LP/HF group, with an average LW of $121.91 \mathrm{~kg}$ and an average age of 229 days. The animals of this breed are usually slaughtered later than those from the other commercial breeds (usually $105-110 \mathrm{~kg}$ of LW in Spain). The Chato Murciano pigs need longer to reach 
the same weights as »commercial« breeds. FISCHER et al. (2006) recorded weights in hybrid pigs (Piétrain-NN $\times$ German Landrace) of 135 and $160 \mathrm{~kg}$ in 206 and 233 days, respectively. Nevertheless, other autochthonous pig breeds show even slower developments, like Iberian pigs (BARBA 1999).

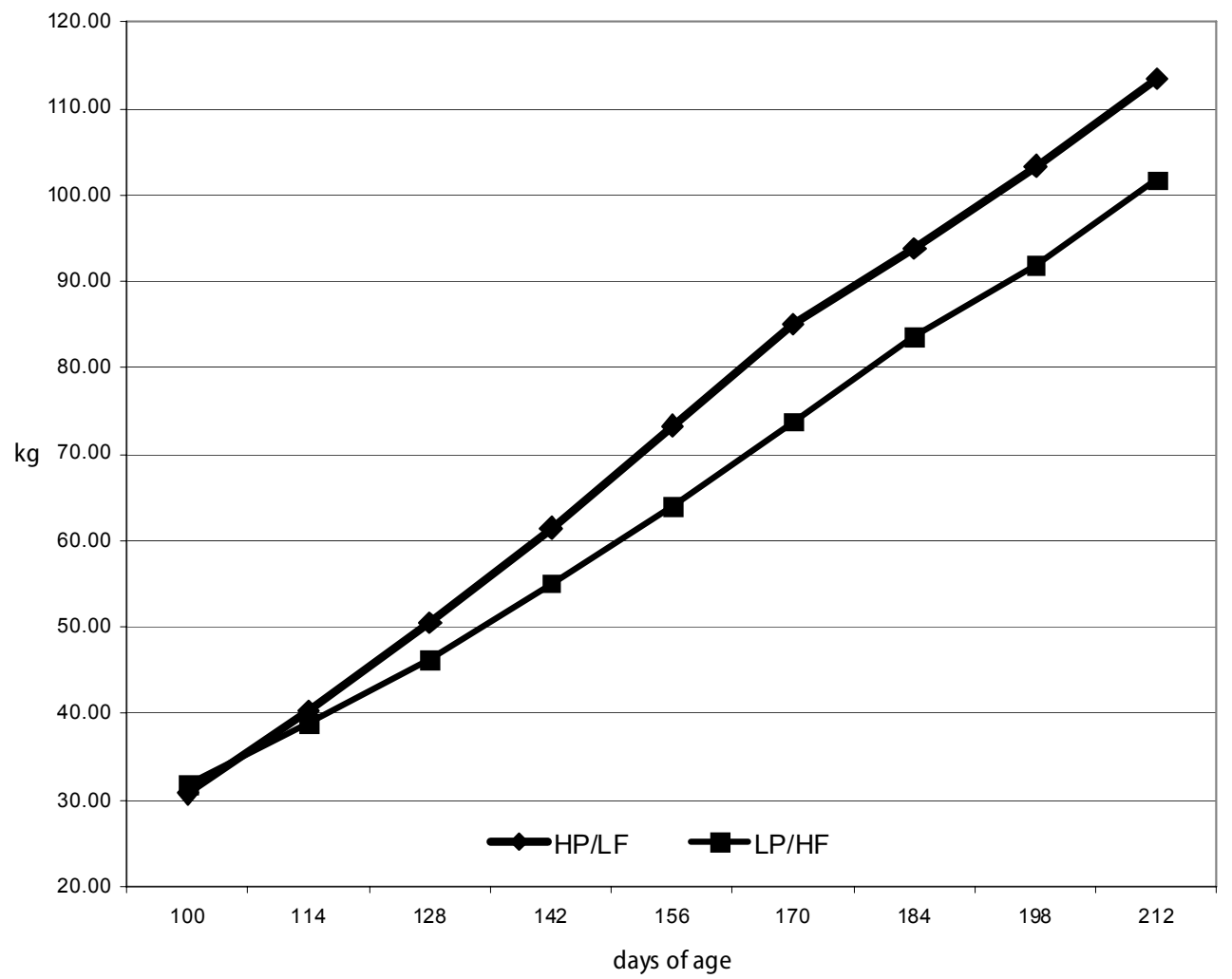

Figure 1

Live weight as a function of age from the day 100 to day 212 of the two groups of pigs fed with the different diets HP/LF and LP/HF.

Lebendgewicht als Funktion der Zeit von Tag 100 bis Tag 212 der zwei Schweinegruppen, die mit den Diäten $H P / L P$ und LF/HF gefüttert wurden.

The live weight as a function of age from day 100 to day 212 in the two groups of pigs is represented in the Figure. As expected, the group with the HP/LF diet showed a clearly faster growing rate $(P>0.05)$, with a daily weight gain (DWG) of $750 \mathrm{~g} / \mathrm{d}$, than the group with the LP/HF diet, which had a DWG of $698 \mathrm{~g} / \mathrm{d}$. Several authors have obtained similar results; pigs fed with low protein diets showed lower growth rates compared to those fed with high protein diets (SAGGAU et al. 2000, WOOD et al. 2004, TEYE et al. 2006, RUUSUNEN et al. 2006).

The weights of the hot carcass and the most valuable meat cuts are represented in Table 2. It should be noted that the hot carcass yield was significantly higher $(P>0.05)$ in the LP/HF group, by contrast with the results obtained by WOOD et al. (2004). In their studies the hot carcass yield was similar with both diets, showing a tendency to a lower carcass yield with the low protein diet. The HP/LF group produced heavier hams with bone $(P>0.05)$, which is the most valuable piece in this breed, due to the subsequent 
production of the typical Spanish »Jamón curado« (cured ham). As expected, high correlations $(P \leq 0.05, P \leq 0.01)$ were found in both groups between the live weight and weight of hot carcass and many of the most valuable meat cuts (Table 2).

Table 2

Correlations in both groups between the LW and weight of hot carcass (HCW) and many of the most valuable meat cuts of the Chato Murciano pigs fed the two diets, HP/LF and LP/HF.

Korrelationen zwischen Lebendgewicht (LW) und Schlachtkörpergewicht (HCW) beider Gruppen in Bezug auf ausgewählte Fleischstücke der mit HP/LP- und LF/HF-Diät gefütterten Chato Murciano Schweine

\begin{tabular}{llccccc}
\hline Parameter & Group & Tenderloin & Loin head & Loin & Shoulder blade & Ham with bone \\
\hline LW & HP/LF & 0.43 & $0.53^{*}$ & 0.39 & $0.73^{* * *}$ & $0.83^{* * *}$ \\
LW & LP/HF & -0.05 & 0.28 & 0.13 & $0.70^{* *}$ & $0.82^{* * *}$ \\
HCW & HP/LF & 0.47 & $0.55^{*}$ & 0.42 & $0.78^{* * *}$ & $0.82^{* * *}$ \\
HCW & LP/HF & 0.09 & 0.36 & 0.21 & $0.69^{* *}$ & $0.86^{* * *}$ \\
\hline
\end{tabular}

${ }^{*} P \leq 0.1, \quad{ }^{* *} P \leq 0.05, \quad{ }^{* * *} P \leq 0.01$

In the Table 3 the levels of dorsal fat thickness (DFT) are shown; these values are considered to be high, and caused to a large extent by the rusticity of the breed. Even though there are no significant differences, the HP/LF group had higher dorsal fat thickness (DFT) values. These values were unexpected, and contrary to those obtained in other studies with commercial breeds (WOOD et al. 2004, TEYE et al. 2006), where the rich protein diets produced lower DFT. The statistical correlations between the different DFT values were very strong in both groups $(P \leq 0.01)$. The morphometric parameters were very similar in both groups (Table 2), and no significant differences were found.

Table 3

Carcass and morphometric parameters of the Chato Murciano pigs fed with the two diets, HP/LF and LP/HF Schlachtkörper und morphometrische Parameter der mit HP/LP- und LF/HF-Diät gefütterten Chato Murciano Schweine

\begin{tabular}{lcc}
\hline & HP/LF Group & LP/HF Group \\
\hline LW and HWC and the most valuable meat cuts, in $\mathrm{kg}^{*}$ & \\
LW & $125.03 \pm 9.75$ & $121.91 \pm 10.32$ \\
Hot carcass & $100.38 \pm 11.34$ & $99.70 \pm 9.13$ \\
Hot carcass yield & $80.39 \pm 1.65^{\mathrm{b}}$ & $81.78 \pm 2.90^{\mathrm{a}}$ \\
Tenderloin & $0.37 \pm 0.05$ & $0.39 \pm 0.09$ \\
Loin head & $1.92 \pm 0.18$ & $1.75 \pm 0.31$ \\
Loin & $2.80 \pm 0.30$ & $2.59 \pm 0.44$ \\
Shoulder blade & $7.39 \pm 0.50$ & $7.26 \pm 0.59$ \\
Ham with bone & $12.27 \pm 0.86^{\mathrm{a}}$ & $11.28 \pm 1.53^{\mathrm{b}}$ \\
Dorsal fat thickness measured at DFT1, DFT2, DFT3, DFT4, in mm & \\
DFT1 & $55.08 \pm 7.38$ & \\
DFT2 & $31.08 \pm 6.24$ & $50.76 \pm 8.78$ \\
DFT3 & $38.39 \pm 8.41$ & $28.88 \pm 5.76$ \\
DFT4 & $30.42 \pm 6.55$ & $35.82 \pm 7.95$ \\
Morphometric parameters, in cm & & $27.05 \pm 7.32$ \\
CL & $85.49 \pm 3.50$ & \\
HL & $34.68 \pm 1.73$ & $83.95 \pm 3.68$ \\
LgL & $59.50 \pm 2.46$ & $34.85 \pm 2.08$ \\
HmL & $36.58 \pm 1.76$ & $59.65 \pm 2.52$ \\
HmP & $74.50 \pm 2.12$ & $37.55 \pm 1.95$ \\
WP & $17.62 \pm 0.85$ & $73.04 \pm 3.52$ \\
\hline
\end{tabular}

*The weight of the most valuable meat cuts refers to one half of the carcass, $a, b$ means differ at $P \leq 0.05$ 
The intramuscular fat content (IMF) in the LL muscle (Table 4) was notably higher in the LP/HF group, which reveals the capacity of the Chato Murciano pig to store excess fat from its diet within the muscles. TEYE et al. (2006) got similar results with two different levels of proteins in their diet (but not such a difference). Other studies in this breed also revealed as well high levels of IMF in the LL muscle, POTO (2003) obtained $6.39 \%$ in pigs reared indoors and GALIÁN et al. (2007) obtained $10.21 \%$ in Chato Murciano pure and $10.43 \%$ in pigs crossed with Iberian pig reared indoors using a LP/HF diet. Many authors have shown the relationship between IMF levels and factors like age and weight at slaughter (WAGNER et al. 1999) and special feeding and rearing conditions (LEBRET et al. 2002, ROSENVOLD and ANDERSEN 2003, KUSEK et al. 2005, NUERNBERG et al. 2005). In this study, the only different factor between the two groups was the diet, and therefore this has to be considered as what produced the big differences in IMF content. The different lysine content of diet ( 0.86 vs. $0.74 \%$ ) could have had an influence; results from other authors (WITTE et al. 2000) pointed out the relationship between the reduced lysine content of diet and a higher IMF content.

Table 4

Meat quality parameters of the Chato Murciano pigs fed with the two diets, HP/LF and LP/HF Fleischqualität der mit HP/LP- und LF/HF-Diät gefütterten Chato Murciano Schweine

\begin{tabular}{lcc}
\hline & HP/LF group & LP/HF group \\
\hline $\mathrm{pH}_{45}$ & $6.34 \pm 0.26$ & $6.20 \pm 0.22$ \\
$\mathrm{pHu}$ & $5.66 \pm 0.08^{\mathrm{a}}$ & $5.61 \pm 0.09^{\mathrm{b}}$ \\
$\mathrm{L}^{*} 45 \mathrm{~min}$ & $45.08 \pm 1.86^{\mathrm{a}}$ & $37.65 \pm 2.16^{\mathrm{b}}$ \\
$\mathrm{a}^{*} 45 \mathrm{~min}$ & $14.90 \pm 1.26^{\mathrm{a}}$ & $5.77 \pm 0.98^{\mathrm{b}}$ \\
$\mathrm{b}^{*} 45 \mathrm{~min}$ & $3.10 \pm 0.54^{\mathrm{a}}$ & $0.07 \pm 0.84^{\mathrm{b}}$ \\
$\mathrm{L}^{*} 24 \mathrm{~h}$ & $50.56 \pm 2.36^{\mathrm{a}}$ & $45.92 \pm 5.42^{\mathrm{b}}$ \\
$\mathrm{a}^{*} 24 \mathrm{~h}$ & $17.89 \pm 1.91^{\mathrm{a}}$ & $8.66 \pm 1.76^{\mathrm{b}}$ \\
$\mathrm{b}^{*} 24 \mathrm{~h}$ & $6.76 \pm 1.52^{\mathrm{a}}$ & $4.05 \pm 3.33^{\mathrm{b}}$ \\
$\mathrm{IMF}(\%)$ & $3.21 \pm 0.89^{\mathrm{b}}$ & $11.00 \pm 5.20^{\mathrm{a}}$ \\
\hline
\end{tabular}

$\mathrm{a}, \mathrm{b}$ means differ at $P \leq 0.05$

FERNANDEZ et al. (1999) indicated that levels over 3.5\% are associated with a significant risk of meat rejection by consumers (referred to fresh meat). Nonetheless, the meat of the Chato Murciano pig is often destined to the production of cured meat products, where high IMF levels offer good technological and sensorial properties. REIXACH (2004) indicated levels of $3.5-4 \%$ as the optimal IMF content for fresh meat destined for cured products.

The $\mathrm{pH}$ values (Table 4) are considered to be normal. There were only significant differences in $\mathrm{pHu}$, with lower values for the LP/HF group. These results are similar those obtained by FLIS et al. (2007), who don't found differences between different diets offered to the pigs.

Table 4 shows the results of colour measurement $\left(L^{*}, a^{*}, b^{*}\right.$ indexes) in the Longissimus lumbar muscle. In all indexes, measured at $45 \mathrm{~min}$ and $24 \mathrm{~h}$ post mortem, the group HP/LF showed higher values than the LP/HF group. However, these results are contrary to those obtained by TEYE et al. (2006), who found higher values of $L^{*}, a^{*}$ and $b^{*}$ in the same muscle in the group with the low protein diet, and RUUSUNEN et al. (2006) who found higher $\mathrm{a}^{*}$ values. Even if there were differences in the mineral content that 
could produce any changes in the colour, the great difference found for the IMF levels might produce those changes in the colour of meat (though no statistical correlations were found). In those animals of the group LP/HF, where the IMF were very high, we observed a great marbling of the meat (not scored, subjective impression).

The LL muscle mineral composition of the two groups studied is represented in Table 5. The diet has a remarkable influence on the meat mineral levels.

Table 5

Mineral composition of the LL muscle of the Chato Murciano pigs fed the two diets, HP/LF and LP/HF

Mineralstoffzusammensetzung des LL Muskels der mit HP/LP- und LF/HF-Diät gefütterten Chato Murciano Schweine

\begin{tabular}{lcc}
\hline Mineral & HP/LF Group & LP/HF Group \\
\hline $\mathrm{Ca}$ & $7.21 \pm 1.95^{\mathrm{a}}$ & $5.13 \pm 1.00^{\mathrm{b}}$ \\
$\mathrm{Mg}$ & $27.16 \pm 0.73^{\mathrm{a}}$ & $21.85 \pm 2.00^{\mathrm{b}}$ \\
$\mathrm{Fe}$ & $2.15 \pm 0.18^{\mathrm{b}}$ & $3.85 \pm 2.57^{\mathrm{a}}$ \\
$\mathrm{Cu}$ & $0.15 \pm 0.02^{\mathrm{b}}$ & $0.29 \pm 0.12^{\mathrm{a}}$ \\
$\mathrm{Zn}$ & $1.61 \pm 0.20^{\mathrm{a}}$ & $1.41 \pm 0.19^{\mathrm{b}}$ \\
$\mathrm{P}$ & $212.11 \pm 3.93$ & $203.12 \pm 8.12$ \\
$\mathrm{~K}$ & $371.19 \pm 14.05^{\mathrm{a}}$ & $345.39 \pm 17.37^{\mathrm{b}}$ \\
$\mathrm{Na}$ & $59.43 \pm 6.31^{\mathrm{a}}$ & $38.77 \pm 6.24^{\mathrm{b}}$ \\
\hline
\end{tabular}

Results expressed in $\mathrm{mg} / 100 \mathrm{~g}$ of raw meat. $\mathrm{a}, \mathrm{b}$ means differ at $P \leq 0.05$

The group that received the HP/LF diet showed significantly higher levels of $\mathrm{Ca}, \mathrm{Mg}, \mathrm{Zn}, \mathrm{K}$ and $\mathrm{Na}$, and significantly lower levels of $\mathrm{Fe}$ and $\mathrm{Cu}$. These differences had to be ascribed to the diet. When we studied the composition of the diet offered to the animals (Table 1), we found that the HP/LF diet had lower levels of $\mathrm{Ca}$ and $\mathrm{Na}$, but, surprisingly, the animals which received this diet had higher levels of these minerals in meat. Similarly, the LP/HF diet had lower levels of $\mathrm{Cu}$ and $\mathrm{P}$, but their content in muscle was higher than in the other group. These contradictory results mean that not only is the chemical composition of food is important; many other factors like ingredients of that diet, and the chemical form in which these elements are presented may increase or decrease their presence in the body and muscle. In addition, the homeostatic mechanisms of the body usually are also able to keep the different mineral levels within a proper range (MILLAR 2000). Information about the contents of other minerals in the diet (such as $\mathrm{Fe}, \mathrm{Mg}, \mathrm{Zn}, \mathrm{K}$ ) was not available. Previous papers about the mineral composition of the LL muscle in the Chato Murciano breed pure and crossed with other breeds show similar results (POTO et al. 2007, GALIÁN et al. 2007), especially to those of the LP/HF group. Taking into account the mineral levels described in food composition tables (MATAIX 2003, CESNID 2004) and different researchers' studies (LEONHARDT and WENK 1997, LOMBARDI-BOCCIA et al. 2005) it can consider that the levels of $\mathrm{Fe}, \mathrm{Cu}$ and $\mathrm{P}$ in our study were high, and the levels of the other minerals can be considered normal.

Particularly interesting and noteworthy are the high levels obtained for iron and copper because of the role of meat in the supply of these elements in our diet. The breed used (whose muscular cells have a high oxidative metabolism, POTO 2003); the diet (especially for the LP/HF group) and the age of slaughter (in this study the pigs were slaughtered at 11 months of age, when usually it is 5-6 months for commercial pigs) can 
explain these high levels. From the correlation coefficients found between the minerals and with other parameters, no conclusions could be pointed out.

The fatty acids on the LL muscle are represented in Table 6.

Table 6

Fatty acid composition (\% of total FA) of the LL muscle of the Chato Murciano pigs fed the two diets, $\mathrm{HP} / \mathrm{LF}$ and LP/HF

Fettsäurenzusammensetzung (\%) des LL Muskels der mit HP/LP- und LF/HF-Diät gefütterten Chato Murciano Schweine

\begin{tabular}{lcc}
\hline Fatty acid & HP/LF group & LP/HF group \\
\hline C14:0 & $1.80 \pm 0.27$ & $1.93 \pm 0.26$ \\
C16:0 & $28.40 \pm 1.77$ & $28.33 \pm 1.46$ \\
C16:1 & $4.66 \pm 0.52$ & $4.91 \pm 0.57$ \\
C18:0 & $11.05 \pm 0.85$ & $10.62 \pm 0.66$ \\
C18:1n-9 & $44.70 \pm 0.99$ & $45.36 \pm 1.06$ \\
C18:2n-6 & $5.65 \pm 1.16$ & $4.88 \pm 1.11$ \\
C18:3n-3 & $0.21 \pm 0.06$ & $0.23 \pm 0.03$ \\
C20:4n-6 & $0.96 \pm 0.28^{\mathrm{a}}$ & $0.75 \pm 0.28^{\mathrm{b}}$ \\
SFA & $42.43 \pm 2.15$ & $42.29 \pm 1.74$ \\
MUFA & $50.34 \pm 1.12^{\mathrm{b}}$ & $51.35 \pm 1.29^{\mathrm{a}}$ \\
PUFA & $7.20 \pm 1.49$ & $6.24 \pm 1.45$ \\
\hline
\end{tabular}

a,b means differ at $P \leq 0.05$

The levels found were quite similar and only those for C20:4 and the MUFA were statistically different $(P \leq 0.05)$. The influence of diet in the fatty acid composition of fat is already known (WOOD et al. 2003, EDWARDS 2005, NUERNBERG et al. 2005, TEYE et al. 2006, VACLAVKOVÁ and BÉCKOVÁ 2007), and diet must have produced the differences found in this study. In the LP/HF group as a tendency and in the HP/LF group as statistically significant, the IMF content showed a positive correlation with the level of SFA and negative with the level of PUFA. The increase of the DFT2 showed a positive correlation with the SFA content and a negative one with the PUFA in both groups, but only as a tendency (not significant). This relationship between the amount of fat (in the IMF, but in the DFT too) and fatty acid levels agrees with the results of other authors (WOOD et al. 2004, GALIAN et al. 2005b, FISCHER et al. 2006b).

All differences showed are due to diets effect, because Chato Murciano pig has high inbreeding.

The present study showed that HP/LF or LP/HF, in the feeding of the Chato Murciano pigs, influences the growing rate and final live weight in relation to age, but morphometric parameters were similar.

The characteristics of the carcass and the meat are also influenced by the diet. Colour index values and $\mathrm{pHu}$ were higher in the LP/HF group. The levels of minerals were influenced by diet, where the HP/LF group had higher levels of $\mathrm{Fe}$ and $\mathrm{Cu}$, but lower levels of $\mathrm{Ca}, \mathrm{Mg}, \mathrm{Zn}, \mathrm{K}$ and $\mathrm{Na}$. The diet had a great influence in the levels of IMF in the $\mathrm{LL}$ muscle, but not in the DFT; the levels of IMF have to be specially considered in the production of cured products. The FA composition was affected by the diet too; the high fat diet produced higher values of MUFA, but no significant differences were found on SFA and PUFA contents. 
In Spain, meat with a high degree of intramuscular fat is well considered, and even more, that meat destined for cured products. Therefore, the meat from Chato Murciano pigs, often destined for the manufacture of cured products, will be expected to produce good quality processed products because of the very high levels of intramuscular fat, and because of its fatty acids profile.

\section{Acknowlegements}

The authors would like to thank the Murcian Institute of Agricultural and Alimentary Research and Development (IMIDA) for the grant and the fellowship of PhD Student Miguel Galián. To the projects BIOCHATO and 2I05SU0025 from the Regional Government of Murcia, to the project no. AGR/13/FS/02 from the SENECA Institution, and the project RTA2005-00163-00-00 from the INIA.

\section{References}

B.O.E. 12/03/1993. (1993) Royal Decree 147/1993, of 29 January, in which the conditions for the production and commercialization of fresh meat are established [in Spanish]

Barba C (1999) Productive characterization of the varieties of the Iberian pig as a basis for their conservation. PhD thesis Córdoba University, Veterinary Faculty, 62-70, 62-70 [in Spanish]

CESNID (2004) Food composition tables. Ed Mc Graw-Hill-Interamericana [in Spanish]

Chiba LI, Kuhlers DL, Frobish LT, Jungst SB, Huff-Lonergan EJ, Lonergan SM, Cummings KA (2002) Effect of dietary restrictions on growth performance and carcass quality of pigs selected for lean growth efficiency. Livest Prod Sci 74, 93-102

Edwards SA (2005) Product quality attributes associated with outdoor pig production. Livest Prod Sci 94, 5-14

Fernandez X, Monin G, Talmant A, Mourot J, Lebret B (1999) Influence of intramuscular fat content on the quality of pig meat. 1. Composition of the lipid fraction and sensory characteristics of $m$. longissimus lumborum. Meat Sci 53, 59-65

Fischer K, Lindler JP, Judas M, Höreth R (2006a) Carcass and meat quality of heavy pigs. I. Experimental design, methods, fattening performance, carcass composition and proportion of cuts. Arch Tierz 49, 269-78 [in German]

Fischer K, Lindler JP, Judas M, Höreth R (2006b) Carcass and meat quality of heavy pigs. II. Characteristics of meat and fat quality. Arch Tierz 49, 279-92

Flis M, Sobotka W, Antoszkiewicz Z, Lipinski K, Zdunczyk Z (2007) Effect of husked and naked oat used in the diets supplemented with linseed oil on the growth performance of pigs carcass and meat quality. Arch Tierz $50 \mathrm{SI}, 161-71$

Galián M, Freudenreich P, Fischer K (2005b) NIRS and NIT as fast methods for determination of fatty acids of pork back fat. Mbl Fleischf Kulmbach 44 170, 305-10 [in German]

Galián M, Peinado B, Martínez C, Periago MJ, Ros G, Poto A (2007) Comparative study of the characteristics of the carcass and the meat of the Chato Murciano pig and its cross with Iberian pig reared indoors. Anim Sci J 78, 659-67

ISO 1443 (1979) Meat and meat content. Determination of Fat

Kusec G, Baulain U, Henning M, Köhler P, Kallweit E (2005) Fattening carcass and meat quality traits of hybrid pigs as influenced by MHS genotype and feeding systems. Arch Tierz 48, 40-9

Lebret B, Massabie P, Granier R, Juin H, Mourot J, Chevillon P (2002) Influence of outdoor rearing and indoor temperature on growth performance carcass adipose tissue and muscle traits in pigs and on the technological and eating quality of dry-cured hams. Meat Sci 62, 447-55

Leonhardt M, Wenk C (1997) Variability of Selected Vitamins and Trace Elements of Different Meat Cuts. J Food Comp Anal 10, 218-24

Lombardi-Boccia G, Lauzi S, Aguzzi A (2005) Aspects of meat quality trace elements and B vitamins in raw and cooked meats. J Food Comp Anal 18, 39-46

Mataix J (2003) Food composition tables. 4th Edition Granada University [in Spanish] 
Millar D (2000) Minerals in Food Chemistry. 2nd Ed, OR Fennema (Ed) Ed Acribia SA, 735-70 [in Spanish]

Nuernberg K, Fischer K, Nuernberg G, Kuechenmeister U, Klosowska D, Eliminowska-Wenda G, Fiedler I, Ender K (2005) Effects of dietary olive and linseed oil on lipid composition meat quality sensory characteristics and muscle structure in pigs. Meat Sci 70, 63-74

Peinado B, Poto A, Marín M Lobera JB (2001) Chato Murciano pig breed. Genetic Conservation of autochthonous breeds (II). Porci. Treatment of pig livestock 61, 39-55 [in Spanish]

Peinado B, Poto A, Gil F, López G (2004) Characteristics of the carcass and meat of the Chato Murciano pig. Livest Prod Sci 90, 285-92

Pfeuffer M (2001) Physiologic effects of individual fatty acid in animal and human body with particular attention to coronary heart disease risk modulation. Arch Tierz 44, 89-98

Poto A (2003) Study of carcass and meat quality of the Chato Murciano pig. PhD thesis. Veterinary Faculty, Murcia University, Spain [in Spanish]

Poto A, Galián M, Peinado B (2007) Chato Murciano pig and its crosses with Iberian and Large White pigs reared outdoors. Comparative study of the carcass and meat characteristics. Livest Sci 111, 96-103

Reixach J (2004) TB-Duroc: Meat quality. http://www.batalle.com/pdfs/pdfs_documents/atec2.pdf [last accessed 24.01.2009] [in Spanish]

Rosenvold K, Andersen HJ (2003) Factors of significance for pork quality - a review. Meat Sci 64, 219-37

Ruusunen M, Partanen K, Pösö R, Puolanne E (2006) The effect of dietary protein supply on carcass composition size of organs muscle properties and meat quality of pigs. Livest Sci doi:10.1016/jlivsci200609021

Saggau E, Beyer M, Klein M, Schadereit R, Derno M, Jentsch W, Scholze H (2000) Effects of dietary protein quality on energy metabolism and thyroid hormone status in growing pigs. Arch Tierz 43, 633-47

Schulte E, Weber K (1989) Rapid preparation of fatty acid methyl esters from fats with trimethyl sulfonium hydroxide or sodium methylate. Fet Wiss Technol 9, 181-3

Teye GA, Sheard PR, Whittington FM, Nute GR, Stewart A, Wood JD (2006) Influence of dietary oils and protein level on pork quality. 1. Effects on muscle fatty acid composition carcass meat and eating quality. Meat Sci 73, 157-65

Václavková E, Bécková R (2007) Effect of linseed in pig diet on meat quality and fatty acid content. Arch Tierz 50 SI, 144-51

Wagner JR, Schinkel AP, Chen W, Forrest JC, Coe BL (1999) Analysis of body composition changes of swine during growth and development. J Anim Sci 77, 1442-66

Warner RD, Kauffman RG, Greaser ML (1997) Muscle protein changes post mortem in relation to pork quality traits. Meat Sci 45, 339-52

Witte DP, Ellis M, McKeith FK, Wilson ER (2000) Effect of dietary lysine level and environmental temperature during the finishing phase on the intramuscular fat content of pork. J Anim Sci 78, $1272-6$

Wood JD, Richardson RI, Nute GR, Fisher AV, Campo MM, Kasapidou E, Sheard PR, Enser M (2003) Effects of fatty acids on meat quality a review. Meat Sci 66, 21-32

Wood JD, Nute GR, Richardson RI, Whittington FM, Southwood O, Plastow G, Mansbridge R, da Costa N, Chang KC (2004) Effects of breed diet and muscle on fat deposition and eating quality in pigs. Meat Sci 67, 651-67

Received 24 April 2008, accepted 24 January 2009.

Corresponding author:

Dr. BEGOÑA PEINADO

email: begona.peinado@carm.es

Murcian Institute of Agricultural and Alimentary Research and Development (IMIDA), Estación Sericícola, C/. Mayor, s/n. 30150 Murcia, Spain 